AperTO - Archivio Istituzionale Open Access dell'Università di Torino

\title{
Shaping Lebanon's borderlands. Armed resistance and international intervention in South Lebanon
}

\section{This is the author's manuscript}

Original Citation:

Availability:

This version is available http://hdl.handle.net/2318/1645637

since 2017-07-25T11:57:34Z

Published version:

DOI:10.1080/13530194.2017.1348455

Terms of use:

Open Access

Anyone can freely access the full text of works made available as "Open Access". Works made available under a Creative Commons license can be used according to the terms and conditions of said license. Use of all other works requires consent of the right holder (author or publisher) if not exempted from copyright protection by the applicable law. 


\section{Shaping Lebanon's Borderlands. Armed Resistance and International Intervention in South Lebanon, I.B. Tauris, 2016.}

This latest book by Daniel Meier sheds new light on the processes of identity construction and state building in Lebanon. The focus of the study is the Country of Cedars' southern region because, as the author explains in the introduction, this part of the country represents a 'vantage point' from which to examine the intricate network of social, cultural and military relationships that have formed over the years in this area; it is also a way "to observe the regional processes that are at work" (p. 4). The South of Lebanon, forgotten by the state, continuously marginalised at both the political and the social level, especially since the end of the civil war, and having suffered continuous violations of its borders and sovereignty (Israeli invasions in 1978, 1982 and 2006), has been able to reinvent itself for the birth and growth of a movement/party that plays a critical role in Lebanese politics today: Hizbullah.

Starting from an analysis of the region's peculiar geography at the crossroads between Israel and Syria, Meier clearly and accurately investigates how and to what extent the porosity of the borders, as well as the fact that the South of Lebanon is a disputed area, produces a process of 'bordering', given that each disruptive event leads to a continual redefinition and remodelling of the border; at the same time, the peculiarity of that region also produces an 'ordering' process that can also alter the balance of power and relations between the actors in and produce a hierarchy of interactions that modify the territory and its identities. As a result of these processes, the 'borderland' is not only a geographical place but also a concept able of producing a 'border effect': the capacity to influence the surroundings area in order to create a distinctive territory. This 'border effect' affects crucial issues such as sovereignty, state- and nation-building processes and identity issues. Studying the boundaries, therefore, is a mental, symbolic and geographical attitude, and this is especially evident in the case of South Lebanon.

How does one 'conceive' a territory amid the continual redefinition of its borders? Has this process of bordering had a tangible effect on the process of identity building and on the actors involved? What are the relationships between such actors? These are the relevant research questions that Meier poses in this book.

To answer these questions, the author focuses on four actors who, from the beginning of the 1980s, have been pivotal to understanding the regional dynamics: The Lebanese state, the Palestinian refugees and their armed resistance, Hizbullah, and the United Nations mission, UNIFIL. Each of these actors has had and continues to have its own agenda with respect to the Lebanese border, and this agenda has had a profound impact on their activities in the region and the interactions with the other actors involved in managing this geographical and symbolic space (Israel, Syria, etc.). Meier investigates the dynamics and the processes of interaction between these actors in their ability to modify the materials/geographical borders. In particular, he examines whether those actors were able to promote, over the years, their own peculiar narrative of the territory, and to what extent this narrative was able to influence the representation of the entire Lebanon. 
The volume is divided into two sections: In the first, which consists of three chapters, Meier, drawing from the work of Bourdieu, analyses how "any struggle over a physical entity is also a struggle over its classification" (p.2). He shows how the military activities (of war or of resistance) that shaped the southern region of Lebanon in some way constituted new identities and produced major socio-economic transformations. The second section of the book, which consists of four chapters, focuses on "borderland narratives". The objective is to show - always through an analysis of the interactions between the four actors mentioned above - that "the meanings of the border are made up of collective experience, cross-border relationships and partnership of authority over this land that have all formed 'mental maps"' (p. 3). Over time, each of the actors has tried to promote its own narrative that and sought to impose it inside and outside the Lebanese space. These narratives have changed the real and symbolic perception of the region and had an impact that goes beyond the mere geographical classification of a territory, namely what is called the process of 'othering'. In the words of Foucault, narratives were a means by which the actors have produced dynamics of subjectivation and governmentality, an instrument that can shape political and social reality.

Relying on years of fieldwork, Daniel Meier uses this new book to put different lines of research that have been at the heart of his studies - the intricate relationship between Palestinian refugees in Lebanon, their identity and the Lebanese political relations in the post-civil war era - to good use, which places the book at the intersection of the multidisciplinary literature on border studies and political sociology. The result is an original volume that, from an innovative perspective, illuminates the complexity of a number of political, social and cultural processes in Lebanon.

Rosita Di Peri, Department of Culture, Politics and Society, University of Torino (Italy) 